\title{
THE ECOFEMINIST SUBSISTENCE PERSPECTIVE REVISITED IN AN AGE OF LAND GRABS AND ITS REPRESENTATIONS IN CONTEMPORARY LITERATURE
}

\author{
PATRICK D. MURPHY \\ University of Central Florida
}

Recibido: 05/03/2013

Aceptado: 09/10/2013

\begin{abstract}
The ecofeminist subsistence perspective arises from years of feminist fieldwork and theoretical elaboration focusing on women as producers of life. It is described as a call to consciousness to reorganize societies and renegotiate global inequalities. Its need for implementation is demonstrated by means of the current international land grabs and their deleterious effects on women's lives, knowledge, and local power. Novels by women writers Buchi Emecheta, Leslie Marmon Silko, Ana Castillo, Toni Morrison, Patricia Grace, and Mahasweta Devi are also discussed in terms of their demonstrating the challenges women face and their efforts to address those challenges by means of various instantiations of the subsistence perspective with varying degrees of achievement and repression.
\end{abstract}

Key-words: ecofeminism, subsistence perspective, land grabs, Buchi Emecheta, Leslie Marmon Silko, Ana Castillo, Toni Morrison, Patricia Grace, Mahasweta Devi.

\section{Resumen}

La perspectiva de subsistencia ecofeminista surge tras años de trabajo de campo feminista y elaboración teórica, centrándose en las mujeres como productoras de vida. Se describe como una llamada a la conciencia para reorganizar las sociedades y renegociar las desigualdades globales. Se ha demostrado la necesidad de su implementación mediante las actuales apropiaciones de tierras internacionales y sus efectos perjudiciales sobre la vida de las mujeres, el saber y el poder local. Las novelas de las escritoras 
Buchi Emecheta, Leslie Marmon Silko, Ana Castillo, Toni Morrison, Patricia Grace y Mahasweta Devi se han analizado con el fin de demostrar los retos a los que se enfrentan las mujeres y sus esfuerzos para abordar esos desafíos por medio de diversas ejemplificaciones de la perspectiva de subsistencia con distintos grados de éxito y represión.

Palabras clave: ecofeminismo, perspectiva de subsistencia, apropiaciones de tierras, Buchi Emecheta, Leslie Marmon Silko, Ana Castillo, Toni Morrison, Patricia Grace, Mahasweta Devi. 


\section{Introduction}

With the global capitalist system in disarray and rolling financial crises making daily headlines during the past several years, it is perhaps a good time to revisit an alternative view of economics to be found in ecofeminist analysis: the subsistence perspective. I find this particular type of ecofeminism particularly relevant for challenging violent and far reaching global economic and ecological manipulations, which aligns it with the global environmental justice movement, and to consider literary works that reflect both the transnational onslaught and responses to it. These contemporary novels come from a variety of national literatures, with distinct styles and settings. Yet, when we consider their themes the in light of environmental justice demands and a subsistence perspective we discover significant commonalities among them.

\section{Subsistence perspective}

The development of the subsistence perspective comes out of years of field work and theoretical elaboration based on the experiences of women in both the Global North and the Global South. It relies on a foundational claim about women and nature as producers of life. Crucially, the defining of this relationship reflects both a holistic sensibility about biological processes and a reconfiguration of the starting point for economic theory. It does not deny the contributions of men, but squarely foregrounds reproduction as the key to production and inverts a series of hierarchical binaries that define the norms of patriarchal cultures, economies, and governments. As the Indian scientist, environmental activist and author, Vandana Shiva, contends,

There are two implications that arise from the recognition of nature and women as producers of life. First, that what goes by the name of development is a maldevelopment process, a source of violence to women and nature throughout the world. This violence does not arise from the misapplication of an otherwise benign and gender-neutral model but is rooted in the patriarchal assumptions of homogeneity, domination and centralization that underlie dominant models of thought and development strategies. Second, that 
the crises that the maldevelopment model has given rise to cannot be solved within the paradigm of the crisis mind. ${ }^{1}$

The subsistence perspective is not only an ecofeminist call to consciousness but also a call to reorganize societies and to renegotiate the global inequalities highlighted by the international environmental justice movement. But, unlike many other such calls to consciousness, social equity is married to ecological sustainability and a systemic approach to the reproducibility of the means for human life without diminishing the lives of other entities.

As Spanish activist Yayo Herrero has made explicit,

... in an ecological perspective, the fundamental contradiction which exists between the present economic metabolism and the durability of the biosphere brings out an important synergy between ecologist and feminist conceptions. The ecological perspective demonstrates the physical impossibility of a society centred on growth. Feminism makes this conflict palpable in our daily lives and denounces the logic of accumulation and growth as being a patriarchal and androcentric logic. ${ }^{2}$

Thus, the so-called essentialism of ecofeminism based on the proximity of women's lives to the rest of nature is revealed as being based on the irreducible commonality of the reproduction of life and the means of life. Shiva in Staying Alive reframes it by means of the lives and work of women in the Global South: "To say that women and nature are intimately associated is not to say anything revolutionary [...] The new insight provided by rural women in the Third World is that women and nature are associated not in passivity but in creativity and in the maintenance of life."

German environmental researcher, activist and author, Maria Mies, and Shiva write that:

Within a limited planet, there can be no escape from necessity. To find freedom does not involve subjugating or transcending the "realm of necessity," but rather focusing on developing a vision of [...] the "good life" within the limits of necessity, of nature. We call this vision the subsistence perspective, because to "transcend" nature can no longer be justified; instead, nature's subsistence potential in all its dimensions and manifestations must be nurtured and conserved. Freedom within the realm of necessity can be universalized to all; freedom from necessity can be available to only a few. ${ }^{4}$

1. SHIVA, Vandana. Staying Alive: Women, Ecology and Development. London, Zed Books, 1989 , p. 46.

2. TORTOSA, Juan. "What is Ecofeminism?" Interview with Yayo Herrero." International Viewpoint Online Magazine December 2011. http://www.internationalviewpoint.org/ spip.php?article2407 Accessed 19-07-2012.

3. SHIVA, Vandana. Op. cit., p. 47.

4. Mies, Maria, and Vandana Shiva, Ecofeminism. London, Zed Books, 1993, p. 8. 
This viewpoint does not call for everyone to return to a hunter-gatherer or agrarian lifestyle, but rather "Consumer liberation and a changed life-style would mean choosing different satisfiers which are neither pseudo nor destructive, which eschew further deterioration of the relationship between human beings and the ecology." After all, "A deep human need cannot be fulfilled by buying a commodity." as a commons to guarantee a minimum foundation for healthy human life: "Without clean water, fertile soils and crop and plant genetic diversity, human survival is not possible. These commons have been destroyed by economic development." Mies with co-author Veronika Bennholdt-Thomsen develops this concept in greater detail in The Subsistence Perspective, but this brief outline here will suffice for now. ${ }^{7}$

Numerous other writers, such as Sabine O'Hara, have broached this topic using different terms, such as "eco-sufficiency" or "provisioning," perhaps avoiding the term "subsistence" because of its atavistic or primitivist connotations. She claims, for instance, that "feminist economists argue that economics should be about 'provisioning' including the provision of productive and reproductive needs and wants." ${ }^{\text {" Moreover, }}$

Feminist ecological economists move ecological and social indicators that better reflect sustaining functions and processes to the fore as well. This means that complexity rather than reducibility, variability rather than specialization, diversity rather than homogeneity, provisioning rather than non-satiation, and the ability to cooperate rather than compete, all become indispensable dimensions of a resilient and sustainable economy. ${ }^{9}$

Ecofeminist Mary Mellor also prefers the term "provisioning."10 The terminology, however, is not as important as the call for a reorientation of economic ideology and how the subsistence perspective can serve as a heuristic device for analyzing culture and literature.

5. MIES, Maria, and Vandana Shiva. Op. cit., pp. 255-256.

6. Mies, Maria, and Vandana Shiva. Op. cit., p. 269.

7. Bennholdt-Thomsen, Veronika, and Maria MIES. The Subsistence Perspective: Beyond the Globalised Economy. Trans. Patrick Camiller, Maria Mies and Gerd Weih. London, Zed Books, 1999.

8. O'Hara, Sabine U. "Feminist Ecological Economics in Theory and Practice," in Ariel Salleh (ed.) Eco-Sufficiency and Global Justice: Women Write Political Ecology. London, Pluto Press, 2009, p. 182.

9. O'Hara, Sabine. Op. cit., p. 190.

10. Mellor, Mary. "Ecofeminist Political Economy and the Politics of Money," in Ariel Salleh (ed.), Eco-Sufficiency and Global Justice: Women Write Political Ecology. London, Pluto Press, 2009, p. 264. 
A current aspect of global economics, the intensifying competition for access to raw materials and land, provides a clear example to consider the efficacy of this orientation. The global resource race by developed and largescale developing economies has intensified the deterioration of the natural reproduction of numerous ecosystems and the social reproduction of numerous tribal, ethnic, and subsistence peoples and communities. While the forces behind this race seek governmental and technological ways to control women's fertility worldwide, they also act to eradicate women's decision making and influence over the production of food, the maintenance of communities, and the continuation of cultures, particularly in the Global South. Although there are many resources under threat of total takeover by transnational corporations to intensify the ecological footprint of dominant economies, here I can focus on only one, the current crisis of major land grabs, its negative impact on women, and the challenges being mounted to these land grabs.

But why do we need to consider the specific issues of gender inequality in relation to agriculture, land ownership, crop selection, and land redistribution, and not just the dimensions of class and ethnicity? Esther Vivas, affiliated with the Center for the Study of Social Movements (CEMS) at Pompeu Fabra University in Barcelona, notes that "In the countries of the Global south women are the primary producers of food, the ones in charge of working the earth, maintaining seed stores, harvesting fruit, obtaining water and safeguarding the harvest. Between 60 to $80 \%$ of food production in the Global South is done by women." Further, she points out that "There is a notable 'feminization' of salaried agricultural work [...] Between 1994 and 2000 [...] women made up $83 \%$ of new employees in the non-traditional agro-export sector." Further, warfare, ethnic cleansing, chronic drought, and erratic weather patterns due at least in part to climate change, as well as the exodus of men from rural communities to seek urban labor and their higher death rates due to AIDS, particularly in Africa, have also placed greater pressures on the women they have left behind. ${ }^{11}$

One need not turn to social activists and feminists for clear statements about differential gendered experiences in agriculture and the disproportionate burden placed on women. The Food and Agricultural Organization (FAO) of the United Nations focused on "Women in Agriculture" in its 2010-11 The State of Food and Agriculture report. In the second paragraph of its Foreword, the authors note that "women face gender-specific constraints that reduce

11. VIVAS, Esther. "Without Women there is No Food Sovereignty." http://esthervivas.com/ english/without-women-there-is-no-food-sovereignty/ Accessed 01-08-2012, pp. 2-3, 4. 
their productivity and limit their contributions to agricultural production, economic growth and the well-being of their families, communities, and countries." 12

\section{Land grabs}

Dominant economic and military states have engaged in the occupation and theft of land from indigenous peoples for millennia. It was the hallmark of eighteenth and nineteenth-century European colonization, and became a mainstay of twentieth-century imperialism as a means of primitive accumulation (see Basu and Harvey), ${ }^{13}$ right on through the post-World War II period of decolonization. Despite gaining nominal political independence many postcolonial states have found themselves remaining exporters of oil, minerals, food, and laborers.

More recently, however, transnational efforts to control agricultural land and through the purchasing or leasing of that land to control water have intensified dramatically (see Pearce). And these actions involve a new range of players, including not only European and American agribusiness conglomerates, but also sovereign wealth funds from Middle East petro states, and private and state owned Indian and Chinese corporations: "land acquisitions for 56.6 million ha [hectares] worldwide-roughly the size of a country like Ukraine-over a period of one year between 2008 and 2009... two-thirds of the land area transacted globally was in Africa, with Southeast Asia also being an important recipient area." Saudi Arabia has bought about half the land acquired in Sudan; China is the major investor in Cambodia and Laos, and even in eastern Russia; in Ethiopia Indian companies account for $71 \%$ of the land area acquired through contracts. ${ }^{14}$

These land grabs, ostensibly planned to increase food security for major economies, increase food insecurity and immediately threaten the economic and cultural lifelines of rural peoples, particularly ethnic minorities and tribals. They also undermine the ecological basis upon which future production will have to be based to feed an increased global population. While a relatively

12. FAO. Food and Agriculture Organization of the United Nations. The State of Food and Agriculture 2010-11: Women in Agriculture. Rome, FAO, 2011, p. vi.

13. BASU, Pranab Kanti. "Political Economy of Land Grab." Economic and Political Weekly, 7 April 2007, pp.1281-1287; HARVEY, David. The New Imperialism. Oxford, Oxford University Press, 2003.

14. Cotula, Lorenzo. "The International Political Economy of the Global Land Rush: A Critical Appraisal of Trends, Scale, Geography and Drivers." Journal of Peasant Studies, 39.3-4 (2012), pp. 651, 657-658. 
small number of rural men benefit in the short term from enhanced wage labor opportunities, the overall impact on the majority of these people, particularly women, are negative and destructive, threatening family and cultural bonds and the relationships of people and their environments.

As Julia Berhman and her co-authors note,

A gender perspective is critical to truly understand the impact of large-scale land deals, because women and men have different social roles, rights, and opportunities and will be differentially affected by any major change in tenurial regimes, especially land transfers to extralocal investors [...] Existing literature on the gender implications of the shift to large-scale commercial agriculture [...] finds that these shifts often lead to changes in household dynamics and roles, income-generation activities, and property rights—often to the detriment of women [...] the rationale for paying attention to gender issues in agriculture derives from a wide-ranging body of empirical evidence that demonstrates the many ways in which women are essential to improvements in household agricultural productivity, food security, and nutrition. ${ }^{15}$

Proponents of the introduction of large-scale agribusiness methods particularly in Asia, Africa, and Amazonia, often cite the benefits of land grabs on the basis of a rise in wage labor opportunities and infrastructure development, but even when the local participants are contract farmers they are wrapped up in long-term lease agreements, credit/debit relationships and the necessity of purchasing expensive fertilizers and pesticides. As Julia and Ben White note, "The establishment of oil plantations on land formerly held and cultivated under customary tenure brings a swift and radical transformation both to the environment and to the social, economic and political structure of local communities." 16

Further, the Whites argue that the subsistence system of maintaining a stable supply of community controlled food is supplanted by reliance on cash purchases of food while the palm oil plantations actually serve as an unreliable source of income. And even though women spend more time in the labor of palm oil plantations and shareholder palm oil cultivation, they engage in more unpaid labor with less control over provisioning for their families and less decision making about income. Whether the land grab involves direct purchase of land, leases of large tracts from the state, or contracts with local

15. BeHRMAn, Julia, et al. The Gender Implications of Large-Scale Land Deals. IFPRI Discussion Paper 01056, January 2011. http://www.ifpri.org/sites/default/files/publications/ ifpridp01056.pdf Accessed 27-08-2012. p. 2.

16. White, Julia, and Ben White. "Gendered Experiences of Dispossession: Oil Palm Expansion in a Dayak Hibun Community in West Kalimantan." Journal of Peasant Studies 39.3-4 (2012), p. 996. 
landowners, a significant loss of biotic diversity quickly occurs in terms of widespread use of pesticides, the introduction of synthetic fertilizers, and the substitution of a single crop for multi-cropping along with the conversion of wild lands and ecotones to cultivated fields. Even local land holders who grow their own palm oil trees and sell the produce remain subject to regional monopsony by the palm oil plantation conglomerates that control processing and international sales. ${ }^{17}$

Lands that are labeled as marginal, and on that basis claimed by the state for sale or lease, are actually vital to women in the Global South, and their loss places additional hardships on them and their families. As Behrman and her co-authors contend, marginal lands are often very important for women for medicinal plants, gathering foodstuffs and firewood, and obtaining clean water, whereas governments often view them as wastelands and encourage their transfer to foreign investors for biofuel production. ${ }^{18}$ Thus, sources for the reproduction of life are destroyed in order to feed cars and trucks with biodiesel. Michael Dove notes that "Great losses of indigenous crops and knowledge have occurred in the past-half century because developmental planners either did not take steps to conserve them or because they took active steps to extinguish them." ${ }^{19}$

\section{Literary representations}

Before turning to literary representations, it is useful to listen to the words of Indian environmental historian Ramachandra Guha:

A striking feature of environmental movements in modern India has been the crucial role played by women. They have taken to the streets to protest forest felling, unregulated mining, displacement, and overfishing. They have also taken the lead in programs of environmental restoration; in the planting up of bare hillsides, in the conservation of local sources of water supply, and in the promotion of energy-efficient technologies. ${ }^{20}$

My foregoing summation of the subsistence perspective and depiction of ongoing land grabs and their impacts particularly on women provide a context for understanding the resistance and activism of the women Guha describes. Combined, they provide a thematic orientation for consideration of

17. White, Julia, and Ben White, op. cit., pp. 1002-1004, 1010, 999.

18. BEHRMAN, Julia, et al., op. cit., 15.

19. Dove, Michael. "The Agronomy of Memory and the Memory of Agronomy," in Virginia D. Nazarea (ed.), Ethnoecology. Tucson, University of Arizona Press, 1999, p. 59.

20. GuHA, Ramachandra. How Much Should a Person Consume? Environmentalism in India and the United States. Berkeley, University of California Press, 2006, p. 58. 
an international set of contemporary novels that either promote a subsistence perspective or encourage a reorientation of economic values in that direction while paying particular attention to the lives and conditions of women.

\subsection{The Rape of Shavi ${ }^{21}$}

The Rape of Shavi by Nigerian novelist Buchi Emecheta has been often described as an "allegory," but more accurately it ought to be considered a parable, intentionally simplistic and stereotypic in its representations of the conflict between a small, remote African village and white British interlopers who crash their plane nearby. Generally dismissed by critics for its one dimensionality and its apparent lack of sophistication compared to her other writing, Rape nevertheless lays out a clear trajectory of the destruction of a subsistence-based economy and culture at the hands of western imperialism. It also suggests that the patriarchal structure of Shavi facilitates the community's domination by the colonizers.

In particular, a westernized prince Asogba returns to Shavi from England during a drought and initiates trade in the extraction of industrial diamond-like stones and he and others encourage the Shavian people to rely on purchasing imported food with the money from their new extractive industry rather than to prepare a sustainable strategy for weathering the next drought. Asogba also plans to import weapons to subdue other tribal peoples in the region. What he does not know is that the market for the Shavian stones has already been saturated and foreign exchange is about to dry up more thoroughly than the desert water holes during a drought. It is the women of Shavi who resist the expansionist plans of the young prince and, after the debacle of his economic conversion of the village and his war against other villages, recommend a return to self-reliance, humility, and subsistence.

At novel's end, one young man who has survived drought and war says to Asogba, "We should go on living the way we used to live, surviving our droughts, cultivating our land." ${ }^{22}$ Emecheta concludes that self-reliance and putting the cultivation of food for local consumption first is the way forward for Africa rather than relying on one failed western development scheme after another. This emphasis on "cultivating our land" seems a strikingly prescient message in light of the enormous land grabs occurring across Africa and threatening the food security of its poorest people. While the novel does not have the stylistic sophistication of her other work, it serves its purpose well

21. EMECHETA, Buchi. The Rape of Shavi. 1983. New York, George Braziller, 1985.

22. EMECHETA, Buchi. Op. cit, p. 178. 
as a cautionary tale that is easily understood precisely because of its overtly didactic theme, which is in keeping with the genre of the parable.

\subsection{Gardens in the Dunes ${ }^{23}$}

Native American author Leslie Marmon Silko surprised many readers when she set the action of her third novel in the last decade of the 1890s and devoted as many pages to the travels of a young Native American girl in Europe as those focused on Native American experience in the Southwest. Silko also provides considerable narration reflecting the concerns and interests of Indigo's white patron, Hattie, since such information could not be represented through a child's point of view. Her traditional realist narrative style in Gardens breaks with the magic realism of her previous two novels, but continues her reliance on long passages of narrative exposition. The novel's action unwinds with a leisurely pace, which some readers may find tedious, but it seems Silko is mimicking the literary conventions of the time period in which it is set. Some critics initially viewed Gardens in the Dunes as an historical novel and found fault with Silko's flagrant violation of chronology, mixing together events that occurred a decade apart and introducing a dam along the Colorado River that was not actually built until three decades after the action of the novel. But Gardens is not a historical novel, although it contains historical events.

Rather, it is a novel as much about the present as well as the past, as Silko herself maintains. ${ }^{24}$ Gardens sets up a contrast between the subsistence economy of the Sand Lizard people, an imaginary tribe near the Colorado River border of California, and the colonizing economy of white settlers. In particular, Silko critiques the biopiracy of empire, whereby European powers stole seeds and plants from colonized people to use for commercial profit and exploitation, replacing localized sustainable agroecology and forestry practices of indigenous peoples for monoculture plantations growing export products. ${ }^{25}$ Silko provides several examples of this biopiracy, a practice that can be compared with transnational corporate efforts today, such as those by Monsanto, to patent or replace native seed stocks with commodified hybrids. The failed attempt by Edward, the novel's main bioprospector, to steal citron

23. Silko. Leslie Marmon. Gardens in the Dunes. New York, Simon \& Schuster, 1999.

24. LI, Stephanie. "Domestic Resistance: Gardening, Mothering, and Storytelling in Leslie Marmon Silko's Garden in the Dunes," SAIL: Studies in American Indian Literatures 21.1 (2009), pp. 20-21.

25. PORTER, Joy. "History in Gardens in the Dunes," in Laura Coltelli (ed.), Reading Leslie Marmon Silko: Critical Perspectives through Gardens in the Dunes. Pisa: Pisa University Press, 2007, pp. 62-63. 
medica cuttings is the best example. A plant used for millennia for medicinal, religious, and sustenance purposes is trivialized as a commodity that Americans want to use for making candies and cakes.

In contrast, Indigo, the young Native American protagonist of Gardens, collects seeds, either given to her as a form of sharing or found in the wild, to cultivate for subsistence combined with aesthetic pleasure. Environmental justice is highlighted through other contrasts as well, such as the decadent, opulent gardens of wealthy New Yorkers, who see no use value in planting and cultivating but design gardens with no attention to environmental suitability as a means of displaying their conspicuous consumption. Further, despite all of the efforts by various forces to the contrary, Indigo, her sister Salt, and other Native peoples manage to return to the Sand Lizard gardens where they lived at the start of the novel to maintain a subsistence economy and rebuild their community, ${ }^{26}$ rejecting the commercial economy only available through assimilation and subordination.

The feminism of the novel comes through not only by means of the conflicts between Native American women and white men representative of a patriarchal capitalist system, but also through a white woman of privilege, Hattie. She is the one who takes Indigo on her and Edward's trip to Europe and who explores the matrifocal religious subculture of Europe. Hattie gradually aligns herself more and more with Indigo and native peoples, turning against her husband, Edward, and her own family. Thus, Silko makes it not a matter primarily of racial conflict but one of resistance to gender oppression, economic exploitation of tribals, and ecological exploitation. ${ }^{27}$

Clear parallels can be seen in the environmental justice struggles occurring today against large scale land grabs, biopiracy, tribal exploitation through primitive accumulation, and intensified oppression of women and the conflicts portrayed in a novel seemingly about events at the end of the nineteenth century. Silko's decision to include the building of a dam that floods the local subsistence community may result from her tying in another parallel aspect of contemporary development projects that destroy indigenous communities for the benefit of urban dwellers and transnational corporations. As Terre Ryan argues,

In Gardens Silko uses the image of the garden to illustrate imperialism on international, national, local, and domestic levels. She accomplishes this by

26. MaGoulick, Mary. "Landscapes of Miracles and Matriarchy in Silko's Gardens in the Dunes" in Laura Coltelli (ed.), Reading Leslie Marmon Silko: Critical Perspectives through Gardens in the Dunes. Pisa, Pisa University Press, 2007, p. 30.

27. LI, Stephanie, op. cit., p. 20. 
pointedly contrasting nineteenth-century American gardening aesthetics and ideologies with the Sand Lizard's subsistence farming [...] Silko describes the ways in which both Native and white women survived by circumventing a system designed to subjugate or destroy them. ${ }^{28}$

\subsection{So Far From God ${ }^{29}$}

While the preceding two novels are set in an imaginary kingdom and another historical period, Chicana author Ana Castillo sets So Far From God in a southwestern American border town heavily dependent on laboring in defense industry manufacturing. Castillo uses this setting to provide an overt environmental justice theme to her novel, one focused on resisting and protesting against toxic working conditions and the super exploitation of minority workers (see Platt). ${ }^{30}$ At the same time, however, Castillo also promotes the engagement and leadership of women not only in fomenting such protests but also in seeking out alternatives to the economy that poisons them as the price for participation in the money economy. So Far from God, although it portrays much pain and sadness, is nevertheless a hilarious novel due to the sophisticated mixture of magic realist techniques and a telenovela plotting with a histrionic narrator.

According to Ronald Walter, Castillo, in all of her fiction is concerned to expose what she calls the "'double sexism, being female and indigenous,' that is, by the Chicana's identity as man's specularized Other, a subject-position conditioned by racism and misogyny." In So Far from God, she does this first through the opposition to the toxic factory conditions that kill Sofi's daughter $\mathrm{Fe}$, the only daughter who completely assimilates into Anglo culture in order to pursue the "American dream." Beyond that Castillo is engaged in "tracing a state of selfhood that involves collective self-definition" as evidenced when Sofi becomes mayor of the town of Tome. ${ }^{31}$

But, as critics have observed, such participation in electoral politics guarantees no change in economic or political status for the community. As Marta Caminero-Santangelo notes, "Though Castillo posits collective agency,

28. RYAN, Terre. "The Nineteenth-Century Garden: Imperialism, Subsistence, and Subversion in Leslie Marmon Silko's Gardens in the Dunes." SAIL: Studies in American Indian Literatures 19.3 (2007), p. 116.

29. Castillo, Ana. So Far From God. 1993. New York, Plume, 1994.

30. See Platt, Kamala. "Ecocritical Chicana Literature: Ana Castillo's 'virtual realism,"” in Greta Gaard and Patrick D. Murphy (eds.), Ecofeminist Literary Criticism: Theory, Interpretation, Pedagogy. Urbana, University of Illinois Press, 1998, pp. 139-157.

31. Walter, Roland. "The Cultural Politics of Dislocation and Relocation in the Novels of Ana Castillo.” MELUS 23.1 (1998), pp. 82, 89. 
especially that of women, as an ideal response to the challenges of environmental degradation and economic injustice, her novel is also concerned with potential threats to any sort of effective, active resistance." 32 Rather, such effective resistance is achieved in So Far from God by means of the development of a subsistence oriented co-operative that partially bypasses the money economy through barter and trade and also privileges the provisioning of the local population over the production of goods and services for the capitalist economy. ${ }^{33}$

As Walter notes, "women are the driving force behind the creation of an alternative space of living, thinking and relating based on justice and equality." ${ }^{34}$ Also, both Walter and Caminero-Santangelo emphasize that the depiction of "the cooperative established by the people of Tome-the novel's most literal scene of collective activism," and a subsistence based economic system are "described in notably realist terms." ${ }^{35}$ Finally, in language paralleling the ecofeminist subsistence perspective, Carminero-Santangelo recognizes, in relation to the highly political Stations of the Cross in the novel decrying environmental injustice, that

This politicized rendering of environmental consciousness demands that such consciousness not romanticize the "natural" at the expense of the human and calls for understanding how damage to the ecosystem has real, material, physical effects on human lives and on woman and on the poorest first. $^{36}$

Thus, Castillo provides an example of the development of an ecofeminist subsistence perspective and its embodiment in an agricultural and handicraft collective in the midst of a town fully enmeshed in the capitalist mode of production, ethnically oppressed, and initially dependent on wage labor employment in toxic manufacturing work.

\subsection{Paradise $e^{37}$}

Certainly, the same remark that Carminero-Santangelo makes about So Far from God could be said to be the case for the women and economic system

32. Caminero-Santangelo, Marta. "The Pleas of the Desperate': Collective Agency versus Magical Realism in Ana Castillo's So Far from God." Tulsa Studies in Women's Literature, 24.1 (2005), p. 82.

33. WALTER, Roland, op. cit., p. 91.

34. Ibid., p. 90.

35. CAMinero-SANTANGElo, Marta, op. cit., p. 84.

36. Ibid., p. 92.

37. MORRISON, Toni. Paradise. 1997. New York, Plume 1999.

Feminismo/s 22, diciembre 2013, pp. 205-224 
of the convent in Paradise, the 1998 novel by Nobel prize-winning African American author Toni Morrison. This novel contains Morrison's trademark lyrical narration, convincing and clearly articulated dialogue, and history reported in the jumbled fashion that it swirls through an individual's mind. Paradise painfully traces the multigenerational trek of African American farmers who settle in Oklahoma seeking to establish an ideal all-black community. Twice the men of this collective establish two new towns, first Haven and then Ruby. But along the way they become rigid and dogmatic, losing their connection to the reproductive foundation of human health to be found in respect for women and for the land, and in the history of the native people who preceded them. As Kristin Hunt puts it,

As the novel progresses, Morrison illustrates how this patriarchal mentality eventually fails to nurture a permanent bond between the townspeople and the land. Trying so desperately to pursue the American dream, the forefathers of the town set up boundaries between themselves, their wives and daughters, and the surrounding land. By choosing to follow the traditional Euroamerican model of being American, the African American settlers separate themselves from the ways of both African cultures and the Arapaho culture [...] But the founders of Ruby are determined to avoid any outside influences that may harm them, including those of nature itself. Ultimately, it is the refusal to accept nature's course and to form bonds with the environment that brings about the demise of the clan's descendants. ${ }^{38}$

The gardens depicted in the town of Ruby demonstrate this disconnection and the complicity of the town's women, in contrast to those of the convent outside the city limits, in a system that severs the bonds between reproduction and subsistence. Hunt points out that these gardens enable the women to compete with each other rather than to reproduce life in order to share and provision, as a result they become another form of conspicuous consumption rather than necessary production..$^{39}$ Thus, we can make clear comparisons between these gardens and the two types presented in Gardens in the Dunes, as well as the agricultural aspects of the Tome cooperative in So Far from God. We can also contrast the disempowerment and alienation of the women in Ruby with their counterparts in Paradise, as well as the Sand Lizard and Tome cooperative women.

38. HunT, Kristin. "Paradise Lost: The Destructive Forces of Double Consciousness and Boundaries in Toni Morrison's Paradise," in John Tallmadge and Henry Harrington (eds.), Reading Under the Sign of Nature: New Essays in Ecocriticism. Salt Lake City, University of Utah Press, 2000, pp. 121-122.

39. Ibid., p. 124.

Feminismo/s 22, diciembre 2013, pp. 205-224 


\subsection{Potiki ${ }^{40}$}

Potiki by Maori author Patricia Grace of New Zealand, which won the 1987 New Zealand Fiction Award, portrays a contemporary struggle by an extended Maori family, with the support of their larger community, against the schemes of a land developer who wants to buy them out in order to turn their small farm and fishing settlement into the beach for an international tourist attraction. It is a short deeply moving novel, at times lyrical and mystical, filled with information about Maori spiritual beliefs and rituals, as well as historical information about efforts by Maori communities, such as the Te Ope, to regain lands taken from them by the white settlers of the islands. Throughout, the resistance of the protagonists, Hemi and Roimata, are guided by a subsistence perspective as the foundation for the economic survival of their family and the reintegration and revitalization of the Maori community. Adopting the slogan that Hemi repeats throughout the novel, "Everything we need is here," they opt for a subsistence form of voluntary poverty and in so doing avoid the self-destruction of becoming disconnected from the foundational features of their extended family and cultural identities. These two, as well as their older children, display a deep commitment to gender equality that is enriched in the course of their struggle for environmental justice and land reclamation.

It is important to realize that their subsistence orientation is not a form of regression, but a progression toward ecological integration and wholeness. As Claudia Duppé remarks, "Māori agricultural practices follow the principles of bio-dynamic farming [...] which the organic food movement considers the most sensible step into a sustainable future. ${ }^{41}$ Grace's novel epitomizes the threat to communal lands, ethnic communities, and ecosystems resulting from the expansion of tourism located in wilderness and so-called "undeveloped" areas.

\subsection{Mahasweta Devi' ${ }^{42}$}

The novels and stories of Bengali activist, essayist, and author, Mahasweta Devi, represent the most sustained fictional representation of the subsistence

40. GRACE, Patricia. Potiki. 1986. Honolulu, University of Hawai'i Press, 1995.

41. Duppé, Claudia. "Ecopolitical Ethics in Patricia Grace's Potiki," in Laurenz Volkmann, Nancy Grimm, Ines Detmers, and Katrin Thomson (eds.), Local Natures, Global Responsibilities: Ecocritical Perspectives on the New English Literatures. Amsterdam, Rodopi, 2010, pp. 128-129.

42. Devi, Mahasweta. Dust on the Road. Trans. Maitreya Ghatak. Calcutta: Seagull Books, 1997; Imaginary Maps: Three Stories by Mahasweta Devi. Trans. Gayatri Spivak. New York, Routledge, 1995. 
perspective by any author currently living. The size and scope of her literary production prevent me from undertaking an adequate discussion of her work here. Consistently committed to exposing the plight and the resistance of the poorest of India's poor and the millions of tribals displaced by various development schemes, she has written both historical novels that serve as metaphors for the present, like Silko's Gardens in the Dunes, and short fiction of the contemporary period that highlight the oppressive conditions for women, such as Imaginary Maps. In all cases, her prose is searing in its intensity, passion, and commitment. She has won numerous literary and humanitarian awards and seen five of her stories turned into films.

Maitreya Gatak comments about one of Devi's essays found in Dust on the Road, which treats material similar to that in some of her stories, and focuses on female migrant laborers in West Bengal brick kilns: "Deprived of their land, with growing restrictions on their access to the forests, with little scope of employment even areas where big industrial projects have come up on what was once tribal land, totally marginalized in their homeland, they have to migrate even in the best of years." ${ }^{43}$ Gatak here points to the intensification of poverty for tribal women as a result of development schemes that have led to deforestation and land grabs that have turned over agricultural commons to industrial and plantation projects, both of which exclude Indian tribals from traditional subsistence activities and from modern wage labor. A good example of the negative impact of land grabs in West Bengal is seen in the spread of eucalyptus plantations, which Devi criticizes. These plantations cause a substantial loss of biodiversity, in particular the elimination of numerous fruit bearing trees for the production of an industrial crop.

\section{Conclusion}

These literary works, and the subsistence perspective that they implicitly or explicitly represent, have a strong anti-capitalist and anti-transnational globalization orientation. As Yayo Herrero contends,

there exists a major contradiction between the process of natural and social reproduction and the process of accumulation of capital. If social reproduction and maintenance of life were the dominant aspect of the economy, activity would be directed towards the direct production of goods of use value and not exchange value, and wellbeing would be an end in itself. ${ }^{44}$

43. GATAK, Maitreya. "Introduction," in Devi, Dust on the Road, p. xxix.

44. HerRero, Yayo, op. cit., p. 2.

Feminismo/s 22, diciembre 2013, pp. 205-224 
And Terisa Turner and Leigh Brownhill in their analysis of women's movements resisting transnational control of resources, conclude, "This resistance specifically affirms subsistence "commoning," by which we mean the affirmation of social relations that realize all the requirements for life on earth and the full development of human capacities" (22-23). They argue, and I would adopt their claim, that "Subsistence as used here is rooted in the local while also being global, future-oriented and hybrid in that it merges selected aspects of pre- and post-capitalist social relations of communing." ${ }^{45}$

An understanding of the current global competition for resources, including agricultural land grabs, provides a basis for recognizing the utility of revisiting the subsistence perspective promoted by Bennholdt-Thomsen, Mies, Shiva, and others. It can serve not only as a lens through which to view local economic struggles and ethnic resistance in the Global South but also as a lens through which to interpret a specific subset of contemporary literature by an international complement of women writers. Such interpretation further enables us to appreciate, research, and teach the themes explored by these writers.

\section{Bibliographic References}

BASU, Pranab Kanti. "Political Economy of Land Grab." Economic and Political Weekly, 7 April 2007, pp.1281-1287.

BEHRMAn, Julia, et al. The Gender Implications of Large-Scale Land Deals. IFPRI Discussion Paper 01056, January 2011. http://www.ifpri.org/sites/default/ files/publications/ifpridp01056.pdf Accessed 27-08-2012.

Bennholdt-Thomsen, Veronika, and Maria MIES. The Subsistence Perspective: Beyond the Globalised Economy. Trans. Patrick Camiller, Maria Mies and Gerd Weih. London, Zed Books, 1999.

Caminero-Santangelo, Marta. "'The Pleas of the Desperate': Collective Agency versus Magical Realism in Ana Castillo's So Far from God." Tulsa Studies in Women's Literature, 24.1 (2005), pp. 81-103.

Castillo, Ana. So Far From God. 1993. New York, Plume, 1994.

Cotula, Lorenzo. "The International Political Economy of the Global Land Rush: A Critical Appraisal of Trends, Scale, Geography and Drivers." Journal of Peasant Studies, 39.3-4 (2012), pp. 649-680.

DevI, Mahasweta. Dust on the Road. Trans. Maitreya Ghatak. Calcutta, Seagull Books, 1997.

45. TURnER, Terisa E, and Leigh S. Brownhill. "We Want Our Land Back: Gendered Class Analysis, the Second Contradiction of Capitalism and Social Movement Theory." Capitalism Nature Socialism 15.4 (1006), pp. 21-40. 
- Imaginary Maps: Three Stories by Mahasweta Devi. Trans. Gayatri Spivak. New York, Routledge, 1995.

Dove, Michael. "The Agronomy of Memory and the Memory of Agronomy," in Virginia D. Nazarea (ed.), Ethnoecology. Tucson, University of Arizona Press, 1999, pp. 45-70.

Duppé, Claudia. "Ecopolitical Ethics in Patricia Grace's Potiki," in Laurenz Volkmann, Nancy Grimm, Ines Detmers, and Katrin Thomson (eds.), Local Natures, Global Responsibilities: Ecocritical Perspectives on the New English Literatures. Amsterdam, Rodopi, 2010, pp. 121-135.

EMECHETA, Buchi. The Rape of Shavi. 1983. New York, George Braziller, 1985.

FAO. Food and Agriculture Organization of the United Nations. The State of Food and Agriculture 2010-11: Women in Agriculture. Rome, FAO, 2011.

GATAK, Maitreya. "Introduction," in Devi, Dust on the Road, pp. vii-li.

GraCE, Patricia. Potiki. 1986. Honolulu, University of Hawai'i Press, 1995.

GUHA, Ramachandra. How Much Should a Person Consume? Environmentalism in India and the United States. Berkeley, University of California Press, 2006.

HARVEY, David. The New Imperialism. Oxford, Oxford University Press, 2003.

HunT, Kristin. "Paradise Lost: The Destructive Forces of Double Consciousness and Boundaries in Toni Morrison's Paradise," in John Tallmadge and Henry Harrington (eds.), Reading Under the Sign of Nature: New Essays in Ecocriticism. Salt Lake City, University of Utah Press, 2000, pp.117-127.

LI, Stephanie. "Domestic Resistance: Gardening, Mothering, and Storytelling in Leslie Marmon Silko's Garden in the Dunes," SAIL: Studies in American Indian Literatures 21.1 (2009), pp.18-37.

MAGoulick, Mary. "Landscapes of Miracles and Matriarchy in Silko's Gardens in the Dunes", in Laura Coltelli (ed.), Reading Leslie Marmon Silko: Critical Perspectives through Gardens in the Dunes. Pisa, Pisa University Press, 2007, pp. 21-36.

Mellor, Mary. "Ecofeminist Political Economy and the Politics of Money," in Salleh, pp. 251-267.

MiEs, Maria, and Vandana Shiva, Ecofeminism. London, Zed Books, 1993.

Morrison, Toni. Paradise. 1997. New York, Plume 1999.

O'HARA, Sabine U. "Feminist Ecological Economics in theory and Practice," in Salleh, pp. 180-196.

PEARCE, Fred. The Land Grabbers: The New Fight Over Who Owns the Earth. Boston, Beacon Press, 2012.

PlatT, Kamala. "Ecocritical Chicana Literature: Ana Castillo's 'virtual realism," in Greta Gaard and Patrick D. Murphy (eds.), Ecofeminist Literary Criticism: Theory, Interpretation, Pedagogy. Urbana, University of Illinois Press, 1998, pp. 139-157.

Feminismo/s 22, diciembre 2013, pp. 205-224 
PORTER, Joy. "History in Gardens in the Dunes," in Laura Coltelli (ed.), Reading Leslie Marmon Silko: Critical Perspectives through Gardens in the Dunes. Pisa, Pisa University Press, 2007, pp. 57-72.

RYAN, Terre. "The Nineteenth-Century Garden: Imperialism, Subsistence, and Subversion in Leslie Marmon Silko's Gardens in the Dunes." SAIL: Studies in American Indian Literatures 19.3 (2007), pp. 115-132.

SAlleH, Ariel, ed. Eco-Sufficiency \& Global Justice: Women Write Political Ecology. London, Pluto Press, 2009.

SHIVA, Vandana. Staying Alive: Women, Ecology and Development. London, Zed Books, 1989.

SILKO. Leslie Marmon. Gardens in the Dunes. New York, Simon \& Schuster, 1999.

TORTOSA, Juan. "What is Ecofeminism?" Interview with Yayo Herrero." International Viewpoint Online Magazine December 2011. http://www.internationalviewpoint.org/spip.php?article2407 Accessed 19-07-2012.

TURnER, Terisa E, and Leigh S. Brownhill. "We Want Our Land Back: Gendered Class Analysis, the Second Contradiction of Capitalism and Social Movement Theory." Capitalism Nature Socialism 15.4 (1006), pp. 21-40.

VIVAS, Esther. "Without Women there is No Food Sovereignty." http://esthervivas.com/english/without-women-there-is-no-food-sovereignty/ Accessed 01-08-2012.

WALTER, Roland. "The Cultural Politics of Dislocation and Relocation in the Novels of Ana Castillo." MELUS 23.1 (1998), pp. 81-97.

White, Julia, and Ben White. "Gendered Experiences of Dispossession: Oil Palm Expansion in a Dayak Hibun Community in West Kalimantan." Journal of Peasant Studies 39.3-4 (2012), pp. 995-1016.

WRIGHT, Laura. "Diggers, Strangers, and Broken Men: Environmental Prophecy and the Commodification of Nature in Keri Hulme's The Bone People," in Bonnie Roos and Alex Hunt (eds.), Postcolonial Green: Environmental Politics and World Narratives. Charlottesville, University of Virginia Press, 2010, pp. 64-79. 